TITLE:

\title{
Reviewed Article: Budongo Forest chimpanzee grooms a red-tailed monkey
}

$\operatorname{AUTHOR}(S)$ :

John, Tinka; Reynolds, Vernon

CITATION:

John, Tinka ...[et al]. Reviewed Article: Budongo Forest chimpanzee grooms a red-tailed monkey. Pan Africa News 1997, 4(1): 6-6

ISSUE DATE:

1997-06

URL:

http://hdl.handle.net/2433/143349

RIGHT:

Copyright (C) Pan Africa News. 


\section{Reviewed Article: \\ Budongo Forest chimpanzee grooms a red-tailed monkey}

\author{
Tinka John \\ Budongo Forest Project \\ and Vernon Reynolds \\ Institute of Biological Anthropology, Oxford University
}

In the last issue of PAN1, Christopher Bakuneeta described a monkey, possibly a hybrid, that moves with a group of chimpanzees at the Kaniyo-Pabidi Ecotourism Site to the north east of the Budongo Forest. It grooms them and is groomed by them. We sometimes send our Field Assistants to do some studies at that site and hence we are in touch with events there.

Here we describe another case of interaction between a monkey and a chimpanzee. It also concerns grooming and other actions by a chimp to a monkey. In this case the identity of the chimp is known and the species of monkey also. The details of the case are as follows, taken from the notes made by John Tinka, a Field Assitant who has been working at the Budongo Forest Project since 1991.

On Wednesday 4th Sept 1996 we (Observers: Kakura James, Jachan Godfrey, and Tinka John) went into the forest to track chimps at $7.30 \mathrm{hrs}$ for our daily data collection. We took line 0 and visited different blocks, in the northern direction from our camp but we didn't see any chimp. At 8:22 we heard calls from Block 1A which covers the area around the sawmill garage. We moved towards this direction. At around 8:40 hrs we found a group of 4 chimps. These included Muga (adult male), Kewaya (adult female), Zimba (adult female) and Gonza (subadult female). These chimps were scattered in different trees at a distance of 7-15 m.

At 8:42 Gonza was in a Khaya anthotheca alone. She was in the southwest of the tree. She saw an adult redtailed monkey which was resting in the north of the same tree. Gonza moved towards the monkey. At a distance of about $3 \mathrm{~m}$ she stopped and got hold of the branch and started to shake it. Possibly she wanted to scare the monkey. But it stayed calm. She repeated the same act 3 times but the monkey never minded. Gonza walked towards the monkey. It was facing the other way. Gonza got hold of its tail and started to shake it. She played with the tail folding it around her neck, shaking it again, this act lasted for 2 minutes. At 8:47 Gonza attempted to groom the monkey below its anus which the monkey accepted willingly. Then real grooming started. The monkey stretched its legs to allow easy reach for Gonza. She groomed it under the abdomen, chest, back. The grooming sometimes was mixed with playing e.g. beating the sides of the monkey, pulling its legs, and Gonza rubbed her vagina against the anus of the monkey. The whole process lasted 20 minutes. And it must be noted that throughout this activity it was Gonza who was the actor only.

At 9:07 the monkey terminated this activity by moving away. Gonza tried to follow, but the monkey moved quickly to another tree then Gonza went to Zimba who is her mother.

\section{Reference}

1. Bakuneeta, C., 1996. Chimpanzees grooming an unknown monkey. Pan Africa News 3 (2): 10. 